\title{
Reciprocity Between Productivity and Credit Growth in Vietnam's Co-operatives Credit Institutions
}

\author{
Van Duong $\mathrm{Ha}^{1}$ \\ ${ }^{1}$ Postgraduate Training Institute, Hong Bang International University, Ho Chi Minh City, Vietnam \\ Correspondence: Van Duong Ha, Postgraduate Training Institute, Hong Bang International University, Ho Chi Minh \\ City, Vietnam. E-mail: dhv05@yahoo.com
}

Received: December 26, 2019

Accepted: January 20, 2020

Online Published: March 5, 2020

doi:10.5430/rwe.v11n1p93

URL: https://doi.org/10.5430/rwe.v11n1p93

\begin{abstract}
Co-operative credit institutions (CCIs) play an important role for achieving the national mission of financial inclusion. Therefore, we should be taking a wider view of productivity and credit and assessing productivity and credit growth. These are factors affecting the CCIs' operations and goals. This study used the panel data regression method with research data from thirty-two selected CCIs in Vietnam from 2013 to 2018. This study's purpose to discover the reciprocity relationship productivity and credit growth in Vietnam's CCIs. By assessing the factors affecting the productivity and credit growth, the research results have determined the bidirectional interactions and causal relationships between productivity and credit growth. Based on the findings the study offers policy implication and new insights for developing a more sustainable CCIs and further emphasizes optimal policies to CCIs management that helps the policy-makers, CCIs managers and executives in improving the overall productivity, and the credit growth of CCIs going forward.
\end{abstract}

Keywords: breadth of outreach, capital adequacy ratio, co-operative financial institution, credit growth, depth of outreach, productivity

\section{Introduction}

The CCIs are the institutions that provide microfinance services and they have an important role in deepening and widening financial inclusion in the country. Their importance in achieving the national mission of financial inclusion because CFIs could contribute significantly in ensuring access to affordable financial services. At the same time, the CCIs play a crucial role in the socio-economic development by bridging the financial exclusion gap created by the traditional financial system through pooling members' savings together for on-lending to the same members. This is an important channel of capital mobilization which has actively contributed to the socio-economic development in Vietnam. However, the major deficiencies in the working of the CCIs are a large reliance on resources mobilised locally and heavy dependence on outside funds. Thus, most of CCIs are faced with various challenges including productivity and credit growth which constantly affect their operations. There has been some research on CCIs operations in Vietnam but, there has been no research on the reciprocity between productivity and credit growth.

This study's purpose was to discover the reciprocity between productivity and credit growth and to examine the factors that affect CCIs' productivity and credit growth. By studying this aspect of Vietnam, multiple regression analysis is used in this study to find out the potential factors that impact to the productivity, and the credit growth of CCIs, and identify research models. The research results will contribute to the theoretical and experimental research on the reciprocity between CCIs' productivity and credit growth. The study contributes to the knowledge gap in the literature on the reciprocity between productivity and credit growth of CCIs. This is the reciprocity which has not been determined so far in the CCIs' operations, especially for the CCIs' operations in Vietnam. It is the gap which should be filling by new research and to close this gap, the study proposes econometric models that show the interaction between productivity and credit growth of CCIs, and the study result clearly shows the reciprocity between productivity and credit growth of CCIs. At the same time, the study offers policy implication and new insights for developing a more sustainable CCIs and further emphasizes optimal policies to CCIs management to change the decision-makers' perception of CCIs, so they can develop an effective suitable management strategy. In which, the policy implication and new insights are included the immediate policy recommendation is for CCIs to focus more on the productivity and the credit growth rate. The CCIs need to strict control over the credit growth quality and efficiency are necessary to 
ensure the productivity growth. The CCIs should attract more clients and members to increase the number of active borrowers. The CCIs need to make every effort to continue its operations restructure and soon complete the restructuring activities. The CCIs need to balance the appropriate capital adequacy ratio to ensure the safe credit growth and contribute to increase the productivity. The CFIs should create many solutions in order to restrict the trade-off between the breadth of outreach and the credit growth rate, the trade-off between the return on assets and the credit growth rate, an the CCIs should make efforts to balance sufficient resources to ensure their operational objectives and create solutions that incorporate the productivity and credit growth goals. Therefore, the study of CCIs' productivity and credit growth is urgently required to improve the productivity and credit growth. In particular, this study is helpful to decision-makers and other stakeholders of CCIs in Vietnam.

\section{Literature Review}

The CCIs engaged in meeting the capital requirements for diversified activities of the members and clients. At the same time, they play a crucial role in the socio-economic development and contribute to strengthening and expanding the formal financial systems. In order to play this role effectively, the CFIs' productivity and credit growth have to be strengthened.

\subsection{Productivity}

The definition of productivity usually depends on the objective of the analysis. In microfinance sector, the productivity indicators of microfinance institution measured as the number of active borrowers by the total number of staff show how efficiently the available human resource is utilized (Rauf \& Mahmood, 2009). The staff productivity ratio is calculated by dividing the number of active borrowers of an microfinance institution by the total number of staff (Rashid \& Twaha, 2013). The higher borrower per staff ratio, the more productive the institution, and the more effectively it leverages is resources to provide financial services to many clients.

Therefore, the CCIs' productivity provides a clue of the number of staff required to produce a given level of output measured by borrowers. The previous literature showed that productivity can be measured in different ways. In this study, the CCIs' productivity is computed by dividing the number of active borrowers by the total number of staff. The productivity is associated with all CFIs' operations, it has been regarded as a prerequisite for continuous improvement the CCIs' operations and is influenced by many factors, including:

First, depth of outreach: According to Rao and Fitamo (2014), the depth of outreach was more important for achieving the social objective of microfinance. It was the average loan size broken down by size dimensions. Quayes (2012) showed the depth of outreach measured by the average loan size per borrower. There were many the impact researches of the depth of outreach on the productivity, in particular Rashid and Twaha (2013) found that the average loan size had an inverse relationship with productivity. The study of Bitok (2019) determined the moderating effect of depth of outreach on the relationship between staff productivity. While, Adhikary \& Papachristou (2014) showed that the depth of outreach and productivity were positively correlated.

Secondly, credit growth rate: According to MicroRate (2014), the productivity had been decreasing in mature markets where was it becoming more difficult to find good borrowers. Therefore, the mature markets where was it becoming more difficult to promote the credit growth and reduce the productivity of microfinance institutions. Abrar (2018) found that the microfinance institutions built a strong client base which in the future results in greater productivity and as competition increases, it put more pressure on microfinance institutions and tended to increase their productivity. Thus, as competition increases, microfinance institutions promoted the credit growth and increased their productivity.

Thirdly, loan-to-deposit ratio: The loans-to-deposits ratio measure the extent that deposit fund loans and is good analysis of the role of deposits as a funding source. This ratio helps to show how well a credit institution is attracting and retaining clients. DiSalvo and Johnston (2017) showed that the loan-to-deposit ratio is a ratio showing how much credit of these institutions was funded by deposits. Loan-to-deposit ratio of large credit institutions reached high ratio as their operations expanded rapidly. Therefore, it has a positive impact on the credit institutions' productivity. According to Ha (2019a), the loan-to-deposit ratio had positive relationships with the credit growth and the number of borrowers. Hence, the loans-to-deposits ratio contributed to increase the microfinance institutions' productivity.

Fourth, breadth of outreach: According to Quayes (2012), the breadth of outreach was measured by the number of people a microfinance institution has extended credit to, or the number of borrowers over a specific period. Abrar (2018) showed that the breadth of outreach is shown by the number of borrower. There were many the impact researches of the breadth of outreach on the productivity, in which Rashid and Twaha (2013) found that numbers of active borrowers positively influenced productivity of microfinance institutions. MicroRate (2014) revealed that the microfinance institutions must learn to maximize productivity by using the least number of resources to process the 
greatest volume of loans and number of borrower in a way that does not sacrifice portfolio quality or customer service. Thereby, the number of borrower had a positivity impact on the microfinance institutions' productivity.

Fifthly, net interest margin: According to MicroRate (2014), this ratio, like the one for microfinance, calculates the interest margin between what the bank pays on its liabilities and the amount the bank charges for its loans. The net iterest margin is calculated as the net interest income (interest paid minus interest received) as a proportion of the average interest earning assets. Saksonova (2014) showed that net interest margin was the most appropriate criterion for evaluating the effectiveness and stability of banks' operations. Therefore, the higher the net interest margin, the more efficient banks are thus productivity may increase. Narwal and Pathneja (2015) pointed out the diversification of activities was more essential to productivity than net interest margin which stated that diversification and net interest margin may lead the banks towards more productivity.

Sixthly, non-performing loan ratio: Kiiru (2007) showed that the microfinance institutions had high repayment rates, which associated with growing the clients and loan sizes. Thus, the microfinance institutions had low non-performing loans ratio, which associated with growing the productivity. Osotimehin et al. (2011) found that the microfinance outreach was positively and significantly determined by loan repayment ratio. Therefore, the numbers of borrowers was positively and significantly determined by loan repayment ratio. This had led to the numbers of borrowers per staff number was negatively and significantly determined by non-performing loan ratio. Arhin et al. (2019) concluded that non-performing loan was a challenge for microfinance institutions. The non-performing loan was major problems for microfinance institutions and had implications on their operations and surviva. Thereby, the productivity of the microfinance institutions was negatively affected with increase in non-performing loans ratios.

Seventhly, return on asset: This is a financial ratio that is commonly defined as net income divided by total assets. The return on assets is a important measurement for profitability of the microfinance institutions. Return on assets is a profitability ratio that provides how much profit a microfinance institutions is able to generate from its assets. Kipesha and Zhang (2013) showed that the return on asset has a negative coefficients with percentage of borrowers per staff in both correlation and regression results. There was the trade-offs between profitability and borrowers per staff. This implied that focusing on profitability resulted into declining outreach to the poor hence existence of trade-offs. However, Adhikary and Papachristou (2014) found that profitability was positively associated with the breadth of outreach. Therefore, the return on assets has a positive impact on the microfinance institutions' productivity. Ha (2019a) also concluded that there was a positive bidirectional interactions relationship between profitability and productivity.

\subsection{Credit Growth}

The credit growth is an increase in the credit supply of CCIs, this has always been the top concern of CCIs. Because reasonable and high-quality credit growth will create stable and safe profitability for CCIs. The credit growth is an operation associated with the development process of CCIs and is influenced by many factors, including:

First, the age of CCIs: Kneiding and Mas (2009) showed that age-related factors can be observed the higher numbers of loans may drive scale economies. Nwachukwu and Asongu (2015) found that the institutional age variable indicates that older microfinance institutions have acquired a comparative advantage from possessing historical records of the income and expenditure streams of their clients. Such could have allowed them to make progressively larger loan sizes. According to Liñares-Zegarra and Wilson (2018), one of the factors affecting the growth of microfinance institutions was age, the new microfinance institutions grew faster than young, and mature counterparts. This shows that the age negatively affected the credit growth of microfinance institutions.

Secondly, productivity: According to MicroRate (2014), the Personnel Productivity Ratio was more useful and more accurate for smaller financial institutions that had a focus on growing their client base. This showed that increasing productivity contributed to the credit growth of microfinance institutions. This study of Rashem and Abdullah (2018) revealed that customer outreach was the important elements for MFI's success, and the lack of customer outreach was the main hindrances for growth and penetration of microfinance institutions. This showed that the increase in the number active borrower per staff led to promote the growth and penetration, and credit growth of microfinance institutions.

Thirdly, capital adequacy ratio: Thampy (2004) found that the bank was faced with an additional regulatory burden in the form of a minimum capital adequacy ratio. The bank had to choose to allocate its assets to maximize revenue and minimum capital adequacy constraint. It was found that minimum capital adequacy requirement was negatively related to loan allocation. The minimum capital adequacy ratio would be increasing, the bank would reduce the supply of loans. Martynova (2015) showed that banks facing higher capital requirements could reduce credit supply as well as decreased credit demand. According to $\mathrm{Ha}(2019 \mathrm{~b})$, capital adequacy refers to the level of capital in an organization that is available to cover its risk. All financial institutions are required to have a minimum amount of capital relative to 
the value of their asset. This study showed that capital adequacy ratio had a negative impact on credit growth of credit institutions.

Fourthly, income: The study of Hellmann et al. (2000) found that in order to maintain or increase their market share, banks were inclined towards credit activity, and the credit expansion was supported by higher income expectations. Hilbers et al. (2006) also showed that the credit expansion was supported by higher income expectations in many banks. Recently, the study results of Bustamante et al. (2019) also signaled that more efficient banks tend to grant more credit.

Fifthly, loan-to deposit ratio: According to Köhler (2012), banks primarily fund their loans by customer deposits as indicated by loan-to-deposit ratios. This showed that the high loan-to-deposit ratios had led to increase the credit growth rate. Ha (2019b) showed that the loan-to-deposit ratio was a key indicator to be monitored to take the gauge of credit institutions' structural liquidity positions, and the loan-to-deposit ratio had a positive relationship with the credit growth of credit institutions

Sixthly, breadth of outreach: According to Quayes (2012), the number of people a microfinance institution has extended credit to, or the number of borrowers over a specific period was considered the breadth of outreach. On the basis the number of active borrowers is defined as individually identifiable borrowers who had at least one current, outstanding loan with the microfinance institution, Abrar (2018) also showed that the breadth of outreach is shown by the number of active borrower. Quayes (2012), showed that from the point of providing clients with access to credit, breadth of outreach can be thought of as measuring the quantity of microcredit. This showed that breadth of outreach had increased both at the industry level and also at the individual microfinance institution level, which had contributed the rapid growth of microcredit. According to the analysis results of Access-Assist (2015), the highest amount of loan portfolio corresponded to the highest loan size and the highest number of active borrowers.

Seventhly, return on assets: According to Awdeh (2017), the return on assets was used a measure of profitability, and bank profitability could be a motive for banks to expand their loans. This revealed that increasing in the return on assets had let to advance the credit growth. The study of Alihodžić \& Ekşi (2018) found there was a positive correlation between bank profitability and credit. Thus, there was a positive relationship between the return on assets and credit growth.

\section{Research Methodology}

The study uses both primary and secondary data and outreach information for CCIs. In the process of extracting the sample from primary and secondary data, the goal was to have as many CCIs with many consecutive years of data as possible. Primary data were original and unique data collected directly from the first-hand source or study object, and these data were collected from the annual reports and financial reports of thirty-two selected CCIs in Vietnam from 2010 to 2018. Secondary data were gathered from international journals, books, or sites related to study conducted. This study tests the following hypothesis on reciprocity between productivity and credit growth: (i) There is a positive relationship between the productivity and the credit growth of CCIs, (ii) There is a positive relationship between the credit growth and the productivity of CCIs. The analysis model of the relationship between the productivity and credit growth of all the CCIs in Vietnam was established as follows:

$$
\begin{aligned}
& \mathrm{Y}_{1}=\alpha_{10}+\alpha_{11} \mathrm{Y}_{2}+\sum_{k=1}^{n} \beta_{1 \mathrm{k}} \mathrm{X}_{1 \mathrm{k}}+\mu_{1} \\
& \mathrm{Y}_{2}=\alpha_{20}+\alpha_{21} \mathrm{Y}_{1}+\sum_{\gamma=1}^{m} \beta_{2 \gamma} \mathrm{X}_{2 \gamma}+\mu_{2}
\end{aligned}
$$

Where,

$Y_{1}$ is a variable that measures productivity, determined by the numbers of borrowers per staff number. $Y_{2}$ is a variable that measures the credit growth, determined the credit growth rate. $X_{1 k}$ and $X_{2 \gamma}$ are the independent variables that can affect productivity and the credit growth in Equation 1, Equation 2 and Equation 3, respectively.

The coefficient $\alpha$ and coefficient $\beta$ are the correlation coefficients of the independent variables with the dependent variables, which are the error terms of the model. For simplicity, indicator $i$ represents the number of observations and indicator $t$ represents the number observed year.

This study used Stata 15.0 software with the variables described briefly and the definitions of the variables and their expected signs are presented in Table 1. 
Table 1. Summary of the research model variables

\begin{tabular}{|c|c|c|}
\hline Variables and symbols & Definition & $\begin{array}{l}\text { Expected sign and } \\
\text { hypotheses }\end{array}$ \\
\hline \multicolumn{3}{|l|}{ Factors affecting productivity } \\
\hline \multicolumn{3}{|l|}{ Dependent variable } \\
\hline $\begin{array}{l}\text { Productivity: Borrowers per staff } \\
\text { ratio (BSR) }\end{array}$ & $\begin{array}{l}\text { Numbers of borrowers / Number of } \\
\text { staff }\end{array}$ & \\
\hline \multicolumn{3}{|l|}{ Independent variables } \\
\hline $\begin{array}{l}\text { Depth of outreach: Average loan } \\
\text { per borrower (ALB) }\end{array}$ & The average loan per borrower & $\begin{array}{l}\text { H1.1: +/- (high ALB, high } \\
\text { or low BSR) }\end{array}$ \\
\hline Credit growth rate (CGR) & Growth in loan outstanding & $\begin{array}{l}\text { H1.2: + (high CGR, high } \\
\text { BSR) }\end{array}$ \\
\hline Loan-to-deposit ratio (LDR) & Total loans / Total deposits & $\begin{array}{l}\text { H1.3: + (high LDR, high } \\
\text { BSR) }\end{array}$ \\
\hline $\begin{array}{l}\text { Breadth of outreach: Number of } \\
\text { active borrowers (NAB) }\end{array}$ & The number of active borrowers & $\begin{array}{l}\text { H1.4: + (high NAB, high } \\
\text { BSR) }\end{array}$ \\
\hline Net interest margin (NIM) & $\begin{array}{l}\text { (Investment return } \quad-\quad \text { Interest } \\
\text { expense) / Average earning assets }\end{array}$ & $\begin{array}{l}\text { H1.5: + (high NIM, high } \\
\text { BSR) }\end{array}$ \\
\hline $\begin{array}{l}\text { Non-performing loan ratio } \\
\text { (NPL) }\end{array}$ & Non-performing loans / Total loans & $\begin{array}{l}\text { H1.6 - (high NPL, low } \\
\text { BSR) }\end{array}$ \\
\hline Return on assets (ROA) & $\begin{array}{l}\text { (Net operating income -Taxes) / } \\
\text { Average assets }\end{array}$ & $\begin{array}{l}\text { H1.7: +/- (high ROA, } \\
\text { high or low BSR) }\end{array}$ \\
\hline \multicolumn{3}{|l|}{ Factors affecting the credit growth } \\
\hline \multicolumn{3}{|l|}{ Dependent variable } \\
\hline Credit growth rate (CGR) & Growth in loan outstanding & \\
\hline \multicolumn{3}{|l|}{ Independent variable } \\
\hline The age of CCIs (AGE) & $\begin{array}{l}\text { Number of operational years of } \\
\text { CFIs }\end{array}$ & $\begin{array}{l}\text { H2.1: +/- (high AGE, high } \\
\text { or low CGR) }\end{array}$ \\
\hline $\begin{array}{l}\text { Productivity: Borrowers per staff } \\
\text { ratio (BSR) }\end{array}$ & $\begin{array}{l}\text { Numbers of borrowers / Number of } \\
\text { staff }\end{array}$ & $\begin{array}{l}\text { H2.2: + (high BRS, high } \\
\text { CGR) }\end{array}$ \\
\hline Capital Adequacy Ratio (CAR) & $\begin{array}{l}\text { Total Capital / Risk Weighted } \\
\text { Assets }\end{array}$ & $\begin{array}{l}\text { H2.3: - (high CAR, low } \\
\text { CGR) }\end{array}$ \\
\hline INcome (INC) & Operating income & $\begin{array}{l}\text { H2.4: + (high INC, high } \\
\text { CGR) }\end{array}$ \\
\hline Loan-to-deposit ratio (LDR) & Total loans / Total deposits & $\begin{array}{l}\text { H2.5: + (high LDR, high } \\
\text { CGR) }\end{array}$ \\
\hline $\begin{array}{l}\text { Breadth of outreach: Number of } \\
\text { active borrowers (NAB) }\end{array}$ & The number of active borrowers & $\begin{array}{l}\text { H2.6: + (High NAB, high } \\
\text { CGR) }\end{array}$ \\
\hline Return on assets (ROA) & $\begin{array}{l}\text { (Net operating income -Taxes) / } \\
\text { Average assets }\end{array}$ & $\begin{array}{l}\text { H2.7: + (High ROA, high } \\
\text { CGR) }\end{array}$ \\
\hline
\end{tabular}

Multiple regression analysis was used in this study to find out the potential factors that affect the formal MFIs' productivity and credit growth. The study used regression analysis on a set of panel data, evaluated the fluctuations of variables and performed the correlation analysis. The study performed the fixed effects estimation according to the fixed effects model (FEM) and performed the random effects estimation according to the random effects model (REM) for estimating the parameters of the empirical data. This research performed the Hausman test and tested for the statistical significance of difference between the coefficients estimates obtained by FEM and by REM. The choice of the two models depends on Hausman tests. The study chose the result between FEM and REM, and compared them 
with the pooled ordinary least square model (OLS) to determine the influencing factors for each model and found the factors affecting productivity, operational sustainability, and the relationships between CCIs' productivity and the credit growth.

\section{Research Results}

\subsection{Descriptive Statistics}

The results of descriptive statistics of both dependent and independent variables showed that the AGE, ALB, BSR, CAR, LDR, NAB, NIM, NPL, ROA variables had smaller standard deviations than the average. In particular, the CCIs operated for many years with a period of from sixteen to twenty-six years. The capital adequacy ratio was more than $8 \%$. Some CCIs had high NPL ratios and suffered losses in their operations. The CGR, INC variables have fluctuations, due to the large difference in the credit growth and income between the CCIs of Vietnam from 2013 to 2018. In particular, the credit size was reduced, and the revenue operations could not cover their cost operations in some CCIs as can be seen in Table 2 .

Table 2. Descriptive statistics

\begin{tabular}{llllll}
\hline Variable & Obs & Mean & Std. Dev. & Min & Max \\
\hline AGE & 192 & 21.27 & 2.012219 & 16 & 26 \\
\hline ALB & 192 & 79.26926 & 38.39886 & 22.12 & 293.89 \\
\hline BSR & 192 & 66.96898 & 26.18056 & 23.76 & 137.6 \\
\hline CAR & 192 & 18.06 & 6.779667 & 8.06 & 41.18 \\
\hline CGR & 192 & .0669519 & .1466848 & -.212 & 1.086 \\
\hline INC & 192 & 204.5032 & 239.9829 & -90.17 & 1054.22 \\
\hline LDR & 192 & 1.041456 & .1961792 & .689 & 1.969 \\
\hline NAB & 192 & 1375.195 & 1171.158 & 241 & 6218 \\
\hline NIM & 192 & 5.067708 & 1.664979 & -1.37 & 9.49 \\
\hline NPL & 192 & 1.201738 & 1.189867 & 0 & 6.36 \\
\hline ROA & 192 & 1.506668 & .9247299 & -3.28 & 4.32 \\
\hline
\end{tabular}

Source: Author's calculation from Stata 15.0.

\subsection{Correlation Analysis}

Collinearity is a condition in which some independent variables are highly correlated, and collinearity between independent variables is a problem to consider in quantitative empirical research. This study performed the correlation analysis between variables in the model and showed a very low degree of correlation among the variables so the presence of any multicollinearity was neglected as can be seen in Table 3 .

Table 3. Correlation matrix

Correlation matrix for factors affecting productivity

\begin{tabular}{lllllllll}
\hline & BSR & ALB & CGR & LDR & NAB & NIM & NPL & ROA \\
\hline BSR & 1.0000 & & & & & & & \\
\hline ALB & -0.3018 & 1.0000 & & & & & & \\
\hline CGR & 0.0434 & -0.0534 & 1.0000 & & & & & \\
\hline LDR & -0.2510 & -0.1606 & 0.1257 & 1.0000 & & & & \\
\hline NAB & 0.5714 & 0.1902 & -0.1212 & -0.3169 & 1.0000 & & & \\
\hline NIM & 0.1074 & -0.4510 & -0.2447 & 0.2082 & -0.0670 & 1.0000 & & \\
\hline NPL & -0.2775 & 0.0882 & 0.0506 & -0.0423 & -0.0228 & -0.2732 & 1.0000 & \\
\hline ROA & 0.3294 & -0.3130 & -0.2543 & 0.0890 & 0.0898 & 0.6415 & -0.3897 & 1.0000 \\
\hline
\end{tabular}


Correlation matrix for factors affecting the credit growth

\begin{tabular}{lllllllll}
\hline & CGR & AGE & BSR & CAR & INC & LDR & NAB & ROA \\
\hline CGR & 1.0000 & & & & & & & \\
\hline AGE & -0.1721 & 1.0000 & & & & & & \\
\hline BSR & 0.0434 & -0.2485 & 1.0000 & & & & & \\
\hline CAR & -0.1833 & 0.0513 & -0.0457 & 1.0000 & & & & \\
\hline INC & -0.1636 & -0.1581 & 0.3609 & -0.1182 & 1.0000 & & & \\
\hline LDR & 0.1257 & 0.1018 & -0.2510 & 0.2640 & -0.3280 & 1.0000 & & \\
\hline NAB & -0.1212 & -0.1293 & 0.5714 & -0.1474 & 0.8424 & -0.3169 & 1.0000 & \\
\hline ROA & -0.2543 & -0.1065 & 0.3294 & 0.2633 & 0.2546 & 0.0890 & 0.0898 & 1.0000 \\
\hline
\end{tabular}

Source: Author's calculation from Stata 15.0.

\subsection{Regression Results}

The study presented the empirical result of the study that were hypothesized in this section. The reciprocity between the CCIs' productivity and credit growth was analyzed with panel data multiple regression analysis.

The BSR was taken as dependent variable and ALB, CGR, LDR, NAB, NIM, NPL, ROA were included as explanatory variables in this study. Regression was carried out using FEM and REM, and compared with OLS between the BSR dependent variable and ALB, CGR, LDR, NAB, NIM, NPL, ROA independent variables.

The result of the fixed effects estimation and random effects estimation showed that both P-values were less than the significance level of $5 \%(\mathrm{P}$-value $=0.000)$, and the regression results were statistically significant at the significance level of $5 \%$. The panel multiple regression used the REM and FEM for estimating the parameters of the empirical data. In the random effects estimation found there were positive relationships between variables CGR, NAB, ROA and the variable BSR at the significance level of $0 \%, 1 \%$ and $5 \%$, respectively; the variables ALB, LDR, NIM and NPL had negative impact on the variable BSR at the significance level of $1 \%, 10 \%, 10 \%$ and $1 \%$, respectively.

In the fixed effects estimation and random effects estimation found there were positive relationships between variables CGR, NAB, ROA and the variable BSR at the significance level of $10 \%, 1 \%$ and $5 \%$, respectively; the variables ALB, NIM and NPL had negative impact on the variable BSR at the significance level of $1 \%, 5 \%$ and $1 \%$, respectively; the variable LDR had a negative impact on the variable BSR, but this variable was not statistically significant as can be seen in Table 4.

The study ran the Hausman test and tested for the statistical significance of difference between the coefficients estimates obtained by FEM and by REM. Hausman test result obtained a P-value of 0.7745 , greater than the significance level of $5 \%$ and by running the Hausman test REM is accepted to be the appropriate model. In comparison with the OLS Pooled model, REM was more suitable than the OLS Pooled model. Hence, REM was used to analyze and test the next steps. The multicollinearity test result showed no serious multicollinearity in this model. Because the model had a result of Mean VIF $=1.81$, VIF of all variables were less than 2,60.

The ability to determine changes in variance was the subject of hypothesis testing for variance. The study considered the problem of testing for a variance change in time series model. Testing for a variance change was considered with the P-value $=1.0000$ and was greater than 0.05 . This result showed it did not have the variance change phenomenon in this model. The study also checked the autocorrelation of the model, P-value $=0.1599$ was greater than 0.05 so this model did not have serial correlation. 
Table 4. Regression results for factors affecting productivity

\begin{tabular}{lll}
\hline Independent variables & Dependent variable (BSR) & \\
\cline { 2 - 3 } & REM & FEM \\
\hline ALB & $-0.288^{* * *}$ & $-0.292^{* * *}$ \\
& $(-6.82)$ & $(-6.31)$ \\
\hline CGR & $23.80^{*}$ & $22.66^{*}$ \\
& $(2.32)$ & $(2.08)$ \\
\hline LDR & $-18.76^{*}$ & -16.01 \\
& $(-2.43)$ & $(-1.93)$ \\
\hline NAB & $0.0131^{* * * *}$ & $0.0130^{* * *}$ \\
& $(10.13)$ & $(9.91)$ \\
\hline NIM & $-2.913^{*}$ & $-3.517^{* *}$ \\
& $(-2.42)$ & $(-2.71)$ \\
\hline NPL & $-4.396^{* * *}$ & $-4.535^{* * *}$ \\
& $(-3.44)$ & $(-3.47)$ \\
\hline ROA & $6.574^{* *}$ & $7.240^{* *}$ \\
& $(3.12)$ & $(3.21)$ \\
\hline cons & $99.85^{* * *}$ & $99.71^{* *}$ \\
\hline P-value & & 0.0000 \\
\hline
\end{tabular}

$\mathrm{t}$ statistics in parentheses $* \mathrm{p}<0.05, * * \mathrm{p}<0.01, * * * \mathrm{p}<0.001$

Source: Author's calculation from Stata 15.0.

The CGR was taken as dependent variable and AGE, BSR, CAR, INC, LDR, NAB, ROA were included as explanatory variables in this study. Regression was carried out using FEM and REM and compared with OLS between the CGR dependent variable and AGE, BSR, CAR, INC, LDR, NAB, ROA independent variables.

The result of the fixed effects estimation and random effects estimation showed that both P-values were less than the significance level of 5\% (P-value $=0.000)$, and the regression results were statistically significant at the significance level of $5 \%$. The panel multiple regression used the REM and FEM for estimating the parameters of the empirical data. In the random effects estimation found there was positive relationships between variable BSR, LDR and the variable CGR at the significance level of 5\% and 5\%, respectively; the variables AGE, CAR, NPL and ROA had negative impacts on the variable CGR at the significance level of $10 \%, 10 \%, 10 \%$ and $1 \%$, respectively; the variable INC had positive impact on the variable CGR, but this variable was not statistically significant. In the fixed effects estimation and random effects estimation found there were positive relationships between variables BSR, LDR and the variable CGR at the significance level of $10 \%, 1 \%$ and 5\%, respectively; the variables NPL and ROA had negative impacts on the variable CGR at the significance level of 5\% and 1\%, respectively; the variable AGE and INC had positive impacts on the variable CGR, and variable CAR had a negative impact on the variable CGR, but these last three variables were not statistically significant as can be seen in Table 5 .

The study ran the Hausman test and tested for the statistical significance of difference between the coefficients estimates obtained by FEM and by REM. Hausman test result obtained a P-value of 0.5365 , greater than the significance level of $5 \%$ and by running the Hausman test REM is accepted to be the appropriate model. In comparison with the OLS Pooled model, REM was more suitable than the OLS Pooled model. Hence, REM was used to analyze and test the next steps. The multicollinearity test result showed no serious multicollinearity in this model. Because the model had a result of Mean VIF = 2.66, VIF of variables from 1.13 to 5.34.

The ability to determine changes in variance was the subject of hypothesis testing for variance. The study considered the problem of testing for a variance change in time series model. Testing for a variance change was considered with the P-value $=1.0000$ and was greater than 0.05 . This result showed it did not have the variance change phenomenon in this model. The study also checked the autocorrelation of the model, P-value $=0.9163$ was greater than 0.05 so this model did not have serial correlation. 
Table 5. Regression results for factors affecting the credit growth

\begin{tabular}{lll}
\hline Independent variables & Dependent variable (CGR) & \\
\cline { 2 - 3 } & REM & FEM \\
\hline AGE & $-0.0121^{*}$ & 0.0183 \\
& $(-2.08)$ & $(1.69)$ \\
\hline BSR & $0.00194^{* *}$ & $0.00182^{* *}$ \\
& $(2.99)$ & $(2.85)$ \\
\hline CAR & $-0.00349^{*}$ & -0.00274 \\
& $(-1.97)$ & $(-1.57)$ \\
\hline INC & 0.000115 & 0.000199 \\
& $(1.08)$ & $(1.87)$ \\
\hline LDR & $0.176^{* *}$ & $0.218^{* *}$ \\
& $(2.75)$ & $(3.30)$ \\
\hline NAB & $-0.0000519^{*}$ & $-0.0000633^{* *}$ \\
& $(-2.16)$ & $(-2.68)$ \\
\hline ROA & $-0.0595^{* * *}$ & $-0.0708^{* * *}$ \\
& $(-3.80)$ & $(-4.45)$ \\
\hline cons & 0.210 & -0.469 \\
& & \\
\hline P-value & 0.0000 & 0.0000 \\
\hline t statistics in parentheses $* p<0.05, * * p<0.01, * * * p<0.001$ & \\
\hline
\end{tabular}

Source: Authors' calculation from Stata 15.0.

\section{Discussions}

\subsection{Discussions of Factors Affecting Productivity}

The results of REM in Table 4 showed that the coefficient of the depth of outreach was negative with coefficient values of -0.288 , and was highly significant at $1 \%$ level of significance with the productivity. This suggested that increasing the average loan per borrower reduced the productivity of CCIs by $28.8 \%$. This result agreed with the analysis results of Rashid and Twaha (2013), Bitok, (2019a) and disagreed with the analysis results of Adhikary \& Papachristou (2014). Many CCIs increased the depth of outreach, the clients were being served and serving the clients required more inputs, which adversely affected the productivity of CCIs.

The regression result indicated that the credit growth rate had a positive and significant impact on the CCIs' productivity with coefficient values of 23.80. Therefore, the hypothesis there was a positive relationship between the credit growth rate, and the productivity of CCIs has been accepted at a $10 \%$ level of significance as it was statistically significant as reported in the model. This result agreed with the analysis results of MicroRate (2014) and Abrar (2018). Given the nature of the CCIs' operation, it required focusing on lending to members, and many CCIs became more difficult to find borrowers and promoted the credit growth, which leaded to a decrease in the CCIs' productivity over the years.

The regression result showed a negative relationship between the loan-to-deposit ratio and the productivity with coefficient values of -18.76 with the significance level of $10 \%$. This result disagreed with the analysis results of DiSalvo and Johnston (2017) and Ha (2019a). Because, the CCIs became more difficult to find borrowers, they increased the average loan size and the fact that the CCIs had a higher average loan per borrower which leaded to an increase in the loan-to-deposit ratio and reduced their productivity over the years.

The regression result indicated that a positive relationship between the breadth of outreach and the CCIs' productivity with a coefficient value of 0.013 . Therefore, the hypothesis there was a positive relationship between the breadth of outreach and the productivity of CCIs has been accepted at $1 \%$ level of significance as it was presented in Table 4 . This result agreed with Rashid and Twaha (2013), MicroRate (2014). The CCIs became more difficult to find borrowers, 
decreased in the total number of active borrowers, which led to reduce their productivity over the years.

The model result indicated the net interest margin had a negative effect on the CCIs' productivity with coefficient values of -2.913 with the significance level of $10 \%$. This result disagreed with the expected sign and hypotheses and disagreed with the analysis results of Saksonova (2014), Narwal and Pathneja (2015). Majority of these CCIs rather charged very high interest rates on their loans and rewarded suppliers of their deposits with low interest rates resulting in high net interest margins. This also causes their difficulties to find borrowers, decreased in the total number of active borrowers, as stated, which led to reduce their productivity over the years. This study also revealed that net interest margin had not yet played an important criteria role for productivity optimization.

The regression result showed a negative relationship between the non-performing loan ratio and the CCIs' productivity with coefficient values of -4.396 with the significance level of $1 \%$. The non-performing loan ratio a very strong negative impact on the CCIs' productivity and statistically highly significant. This implied that the credit risk of CCIs had significance effect in determining their productivity. This result agreed with the expected sign and hypotheses and agreed with the analysis results of Kiiru (2007), Osotimehin et al. (2011) and Arhin et al. (2019). Many of CCIs had the low non-performing loan ratio and increased the productivity due to their non-performing loan ratio decreased in previous years. The non-performing loan ratio reduced the CCIs' productivity, so many CCIs maintained low non-performing loan ratio, attracted borrowers and increased their productivity. In contrast, some CCIs had high non-performing loan ratio, had difficulty attracting borrowers, which led to a decrease in their productivity.

The results showed that the coefficient of the return on assets was positive, and was significant at $5 \%$ level of significance with the CCIs' productivity, indicating that ROA had a strong impact on the productivity. The coefficient magnitudes for the return on assets was 6.574 in the model, suggesting that increasing the return on assets improved the productivity of CCIs by 6.574 units per year. The estimation result was consistent with the expectation that return on assets was associated with an increase of the CCIs' productivity. The findings of this study were consistent with prior empirical studies by Adhikary and Papachristou (2014), $\mathrm{Ha}$ (2019), but this result disagreed with the analysis results of Kipesha and Zhang (2013). In addition to serving its members goals, the aim of the CCIs were to seek profit like many other financial institutions. The profitability was one of the most important criteria for the CCIs' productivity optimization, it contributed to increase the CCIs' productivity. This study found that the CCIs' return on assets had a positive impact on productivity and this study result also showed there was the interactive relationship between the CCIs' return on assets and productivity.

\subsection{Discussions of Factors Affecting the Credit Growth}

The results of REM in Table 5 showed a negative relationship between the age of CCIs and the credit growth rate with coefficient values of -0.0121 . Hence, the hypothesis that stated the age of CCIs had a significant impact on their credit growth rate has been accepted at a $10 \%$ level of significance as it was statistically significant as reported in the model. This result agreed with the analysis results of Liñares-Zegarra and Wilson (2018) and disagreed with the analysis results of Kneiding and Mas (2009), Nwachukwu and Asongu (2015). The age of CCIs reflected operational experience of CCIs, but it was negatively and statistically significantly related to the credit growth, which implied that for any additional year of existence of the CCIs, the credit size decreased over the years. Through this result showed that the experience did not yet play the important role in dealing with the clients as it did not yet provide chance for lenders and borrowers to understand each other and served each other more efficiently. Many CCIs had the higher the age, the smaller the credit growth over the years.

The results showed that the coefficient of the productivity was positive, and was significant at $5 \%$ level of significance with the credit growth rate, indicating that the productivity had a strong impact on the credit growth rate. The coefficient magnitudes for the productivity was 0.00194 in the model, suggesting that increasing the productivity advanced the credit growth rate of CCIs by $0.194 \%$. The estimation results are consistent with the expectation that productivity associated with an increase of the CCIs' credit growth rate. This result agreed with the analysis results of MicroRate (2014), Rashem and Abdullah (2018). This implied that the increasing the productivity resulted into more than the credit size. When increasing the number of borrowers per staff corresponded to the increase in productivity, and the increase in the number of borrowers leading to increase demand for credit, the CCIs disbursed to meet this need, thereby contributing to credit growth. The reciprocity between productivity and credit growth was clearly shown by the practical operation of CCIs in Vietnam. The fact that many CCIs increased the productivity contributes to the credit growth. On the contrary, the other CCIs had not only shown lower number of borrowers coupled with much lower the productivity but also a slower growth in their credit over the years.

The results indicated negave relationship between the capital adequacy ratio and the credit growth rate with coefficient value of -0.00349 . Therefore, the hypothesis that stated the capital adequacy ratio and of CCIs had an impact on the 
credit growth rate has been accepted at $10 \%$ level of significance as it is indicated in the model. This result agreed with the expected sign and hypotheses and agreed Thampy (2004), Martynova (2015) and Ha (2019b). The implication of this finding was the higher capital adequacy ratio, the less credit supply it would use. Therefore, it was not surprising that the higher capital adequacy ratio reduced credit supply as well as decreased the credit growth rate. Many CCI maintained high capital adequacy ratio because they did not yet select their asset allocation to maximize revenue, besides, they had difficulty in finding the clients and expanding the credit size over the years.

The regression result showed a positive relationship between the loan-to-deposit ratio and the credit growth rate with coefficient values of 0.176 with the significance level of $10 \%$. This result agreed with the expected sign and hypotheses and agreed with the analysis results of Köhler (2012) and $\mathrm{Ha}$ (2019). The reduced lending capacity of the CCIs was one of the factors that had contributed to a sharp slowdown of credit growth. However, another factor contributed to increase the credit growth rate in some CCIs was the loan-to-deposit ratio.

The study result showed a negative relationship between the breadth of outreach and the credit growth rate with coefficient values of -0.0000519 with the significance level of $10 \%$, suggesting that increasing the breadth of outreach reduced the credit growth rate of CCIs by $0.00519 \%$. This result implied that the number of active borrowers of CCIs had effect in determining the credit growth rate. The finding of this study was inconsistent with prior empirical studies by Quayes (2012) and Access-Assist (2015). There was a trade-off between the breadth of outreach and the credit growth rate of CCIs. The client attract capacity of CCIs reduced the number of active borrowers which was one of the factors that decreased to a sharp slowdown of credit growth.

The results also showed that the coefficient of the return on assets was negative, and was significant at $1 \%$ level of significance with the credit growth rate, indicating that ROA had a very strong impact on the credit growth rate. The coefficient magnitudes for the return on assets was -0.0595 in the model, suggesting that increasing the return on assets reduced the credit growth rate of CCIs by $5.95 \%$. The estimation result was inconsistent with the expectation there was a positive relationship between the return on assets, and the credit growth of CCIs. The finding of this study was in inconsistent with prior empirical studies by Awdeh (2017), Alihodžić \& Ekşi (2018). This study found there was a trade-off between the return on assets, and the credit growth rate of CCIs. Many CCIs have restructured their operations and were more interested in serving its members and profits than the credit growth over the years.

The regression results were accurate according to the characteristics of CCIs and the development process of CCIs in Vietnam from 2013 to 2018. On the other hand, this study did not find statistically significant impacts between the income and the credit growth rate. This was consistent with the fact that CCIs step by step improve their operation capacity by their restructure operations, and most of CCIs ensured the income and their profitable operation. This again showed that CCIs were interested in serving its members and operational efficiency over the years.

\section{Conclusions and Recommendations}

The productivity and credit growth rate of CCIs were an economic topic and were influenced by many factors. Stemming from the important role of CCIs in the socioeconomic development, this study has found the relationship between the productivity and credit growth rate of the CCIs in Vietnam. Multiple regression analysis was used to find out the potential factors that affect the productivity and credit growth rate of the CCIs. The two prominent models were identified and these research results were consistent with the characteristics, and the development history of CCIs in Vietnam from 2013 to 2018.

This study performed to identify the factors that were affecting the productivity and credit growth rate of CCIs. At the same time, the econometric analysis suggested that the productivity and credit growth rate of CCIs influenced each other. This study found bidirectional causal interactions between both the productivity and credit growth rate with each other in a positive trend. Based on the research results, the article recommends key content the following to advance the productivity and improve the credit growth rate of CCIs in Vietnam.

Firstly, this study found a positive bidirectional causal interaction between the productivity and the credit growth rate, so that the immediate policy recommendation is for CCIs to focus more on the productivity and the credit growth rate. At the same time, CCIs need to strict control over the credit growth quality and efficiency are necessary to ensure the productivity growth.

Secondly, CCIs should attract more clients and members to increase the number of active borrowers. In addition, CFI should focus on mobilizing deposits from clients and members in order to become self-sustaining and create the capital resource to meet the needs of many borrowers. This creates a suitable loan-to-deposit ratio to meet the needs of the borrower and contributes to increase the productivity and credit growth.

Thirdly, CCIs need to make every effort to continue its operations restructure and soon complete the restructuring 
activities. At the same time, the CCIs need to balance the appropriate capital adequacy ratio to ensure the safe credit growth and contribute to increase the productivity.

Fourthly, CFIs should create many solutions in order to restrict the trade-off between the breadth of outreach and the credit growth rate, the trade-off between the return on assets and the credit growth rate.

Fifthly, increasing the productivity and credit growth rate are the right conditions and opportunities to make them vibrant medium to serve credit needs of the members and clients, and these contribute to promote the financial inclusion in Vietnam. So that, CCIs should make efforts to balance sufficient resources to ensure their operational objectives and create solutions that incorporate the productivity and credit growth goals.

\section{References}

Abrar, A. (2018). The impact of financial and social performance of microfinance institutions on lending interest rate: A cross-country evidence. Cogent Business \& Management, 6, 1540072. https://doi.org/10.1080/23311975.2018.1540072

Access-Assist. (2015). Outreach of Microfinance Finance Institutions in four focus states. A Consolidated report on analysis of MFIs outreach in Bihar, Odisha, M.P., and U.P. Retrieved December 18, 2019, from https://sidbi.in/files/article/articlefiles/j\%20(vii).pdf

Adhikary, S., \& Papachristou, G. (2014). Is There a Trade-off between Financial Performance and Outreach in South Asian Microfinance Institutions?. The Journal of Developing Areas, 48(4), 381-402.

Alihodžić, A., \& Ekşi, I. H. (2018). Credit growth and non-performing loans: evidence from Turkey and some Balkan countries. Eastern Journal of European Studies, 9(2), 229-249.

Arhin, E., Issifu, R., Akyeampong, B., \& Opoku, I. N. (2019). Analysis of Non-Performing Loans (NPL) among Microfinance Institutions (MFIs) in Ghana: Evidence from the Kasoa Municipality. Journal of Economics, Management and Trade, 22(5), 1-10, https://doi.org/10.9734/jemt/2019/v22i530100

Awdeh, A. (2017). The Determinants of Credit Growth in Lebanon. International Business Research, 10(2), 9-19.

Bitok, S. K. (2019). The moderating effect of depth of outreach on the relationship between financial leverage and financial sustainability of microfinance institution. Journal of Economic and Business Studies, 2(7), 136. Retrieved December $\quad 19, \quad 2019, \quad$ from https://www.pubtexto.com/pdf/?the-moderating-effect-of-depth-of-outreach-on-the-relationship-between-financ ial-leverage-and-financial-sustainability-of-microfin

Bustamante, J., Cuba, W., \& Nivin, R. (2019). Determinants of credit growth and the bank lending channel in Peru: A loan level analysis. BIS Working Papers, No 803. Bank for International Settlements. Retrieved December 18, 2019, from https://www.bis.org/publ/work803.pdf

DiSalvo, J., \& Johnston, R. (2017). Banking Trends: The Rise in Loan-to-Deposit Ratios: Is 80 the New 60?. Federal Reserve Bank of Philadelphia, 2(3), 18-23.

Ha, V. D. (2019a). The interactive and causal relationship between productivity and profitability of Vietnam's formal microfinance institutions. Asian Economic and Financial Review, 9(10), 1160-1170.

Ha, V. D. (2019b). The Interactive Relationship between Credit Growth and Operational Self-Sustainability of People's Credit Funds in Mekong Delta Region of Vietnam. The Journal of Asian Finance, Economics and Business, 6(3), 55-65.

Hellmann. T., Kevin, M., \& Stiglitz, J. (2000). Liberalization, Moral Hazard in Banking and Prudential Regulation: Are Capital Requirements Enough?. American Economic Review, 90(1), 147-165.

Hilbers, P., Otker-Robe, I., \& Pazarbacsiouglu, C. (2006). Going too Fast? Managing Rapid Credit Growth in Central and Eastern Europe. IMF Finance and Development, 43(1), 42-45.

Kiiru, J. M. M. (2007). Microfinance: Getting Money to the Poor or Making Money out of Poverty?. International Journal of Finance and the Common Good, 27(11), 64-73.

Kipesha, E. F., \& Zhang, X. (2013). Sustainability, profitability and outreach tradeoffs: Evidences from microfinance institutions in East Africa. European Journal of Business and Management, 5(8), 136-148.

Kneiding, C., \& Mas, I. (2009). Efficiency Drivers of MFIs: The Role of Age. CGAP brief. Washington, DC: World Bank. Retrieved December $20, \quad$ 2019, from http://documents.worldbank.org/curated/en/834271468164639801/Efficiency-drivers-of-MFIs-the-role-of-age 
Köhler, M. (2012). Which banks are more risky? The impact of loan growth and business model on bank risk-taking. Discussion Papers, 33/2012, Deutsche Bundesbank. Retrieved December 19, 2019, from https://ssrn.com/abstract=2796886

Liñares-Zegarra, J. M., \& Wilson, J. O. S. (2018). The size and growth of microfinance institutions. The British Accounting Review, 50(2), 199-213.

Martynova, N. (2015). Effect of bank capital requirements on economic growth: a survey. DNB Working Papers 467, Netherlands Central Bank, Research Department. https://doi.org/10.2139/ssrn.2577701

MicroRate. (2014). Technical Guide: Performance and Social Indicators for Microfinance Institutions. Industry research report. Lima, Peru.

Narwal, K. P., \& Pathneja, S. (2015). Determinants of productivity and profitability of Indian banking sector: A comparative study. Journal of Business and Economics, 8(16), 35-58.

Nwachukwu, J. C., \& Asongu, S. (2015). The Determinants of Interest Rates in Microbanks: Age and Scale. Working Papers of the African Governance and Development Institute. 15/004, African Governance and Development Institute. Retrieved December 20, 2019, from https://mpra.ub.uni-muenchen.de/67298/

Osotimehin, K. O., Jegede, C. A., \& Akinlabi, B. H. (2011). Determinants of microfinance outreach in South-Western Nigeria: An empirical analysis. Interdisciplinary Journal of Contemporary Research in Business, 3(8), 790-797.

Quayes, S. (2012). Depth of outreach and financial sustainability of microfinance institutions. Applied Economics, 44(26), 3421-3433.

Rao, R. M., \& Fitamo, T. L. (2014). Concepts and measures of outreach and sustainability in microfinance institutions: A comprehensive literature review. Research Journal of Finance and Accounting, 5(21), 41-48.

Rashem, N., \& Abdullah, Y. A. (2018). Factors influence the growth and penetration of microfinance institutions: A case of Egypt. Academy of Accounting and Financial Studies Journal, 22, Special Issue. Retrieved December 20, 2019, from https://www.abacademies.org/special-issues/volume-22-special-issue.html

Rashid, A., \& Twaha, K. (2013). Exploring the determinants of the productivity of Indian microfinance institutions. Theoretical and Applied Economics, 10(12), 83-96.

Rauf, S. A., \& Mahmood, T. (2009). Growth and performance of microfinance in Pakistan. Pakistan Economic and Social Review, 47(1), 99-122.

Saksonova, S. (2014). The role of net Interest margin in improving Banks' asset structure and assessing the stability and efficiency of their operations. Procedia - Social and Behavioral Sciences, 150(2014), 132-141.

Thampy, A. (2004). Bis Capital Standards and Supply of Bank Loans. SSRN Electronic Journal. https://doi.org/10.2139/ssrn.561723 